\author{
Case Study \\ www.ijrap.net (ISSN:2229-3566)
}

\title{
PERTINENCE OF KSHARA KARMA AND AGNI KARMA IN THE MANAGEMENT OF MASAKA WITH SPECIAL REFERENCE TO ELEVATED MOLE: A CASE STUDY
}

\author{
Himadri Mudgal ${ }^{1 *}$, P. Hemantha Kumar ${ }^{2}$ \\ ${ }^{1}$ P.G. Scholar, Department of Shalya Tantra, National Institute of Ayurveda, Jaipur, Rajasthan, India \\ ${ }^{2}$ Professor and Head of Department, Department of Shalya Tantra, National Institute of Ayurveda, Jaipur, Rajasthan, \\ India
}

Received on: 12/07/20 Accepted on: 29/08/20

\author{
*Corresponding author \\ E-mail: drhimadrimudgal52@gmail.com
}

DOI: 10.7897/2277-4343.1105134

\begin{abstract}
Moles are a commonest skin condition. They are usually small, dark brownish, black spots and are caused by groups of pigmented cells. Mole can appear anywhere on the skin either alone or in groups. They usually appear in childhood and adolescence. In Ayurvedic classics it is usually correlated with Masaka. Masaka (elevated mole) are caused by vitiated Vatadosha as painless, black gram colour elevated and stable identity. In the present study a male patient aged about 42 years came complaining of a blackish brown coloured growth with irregular margins present on right side of his face (infraorbital region). With time the discoloured growth gradually increased its size in last 15 years. In contemporary medicine various treatments of this condition are available but no promising management is updated till date. Keeping this in mind the patient was advised to undergo Agnikarma and Kshara karma. By help of Agnikarma the mass was excised and later Kshara was applied. Since moles usually reoccur after excision also, Application of Kshara plays a pivotal role here since it leaves less possibility for it to regrow. After the above said treatment patient was advised to apply Jatyadi tail which is very good Vrana Ropak. After the follow up of 2 months it was found that there was no reoccurrence. The aim of study is to highlight the role of Agnikarma and Kshara karma in Masaka with special reference to elevated mole.
\end{abstract}

Keywords: Masaka, Agnikarma, Kshara karma, Elevated mole.

\section{INTRODUCTION}

The skin is the largest organ in the body. It safeguards our body from external environment by building a wall. Now days; the risk of skin disorder is rising. Every unhealthful state of the body is expressed in the skin as beauty shows through the complexion of the skin. The importance of appearance and personality is at its best in this artistic era as it defines social perceptions, interest, decision and interpersonal relationships. Skin disorders vary greatly in symptoms and severity. They can be temporary or permanent and may be painless or painful some could be minor while some can be lethal ${ }^{1}$. Moles are pigmented skin growths having different colours may be brown, black, and even bluish sometimes. Moles may appear solitary or in clusters at any part of body. Moles usually appear during childhood and before the age of 20. Rarely do they appear in later phase of life. It's common for an average adult to have 10 to 40 moles $^{2}$.

Appearance of moles may change with time. They may become elevated or sometimes there will be a slight change in colour. A mole can be a flat mole, or a raised mole based on their presence in the skin layer. They are also known as pigmented nevi or melanocytic nevi ${ }^{3}$.

Although the number of moles varies from person to person, fairskinned people appear to have more moles because they have lower levels of melanin in their skin. The average number of moles is between 10 and 40 in adults. Moles may even appear and disappear with hormonal changes like pregnancy or puberty. Many people naturally grow more moles on their skin with exposure to age and sunlight, and usually moles do not cause any harm ${ }^{4}$. Moles (Masaka) are classified into two types according to Acharya Sushruta. One is flat and the other is elevated. Black,
Sesamum-like, painless and even marks appear due to drying of Kapha by Vata and Pitta. They are known as Tilakalaka (flat mole) $)^{5}$. Masaka (raised mole) is painless, hard, raised and black like gram appearing on body parts due to vata ${ }^{6}$.

Moles can be removed surgically ${ }^{7}$. Fading or lightening creams, bleaches, freezing, or other chemicals usually do not any role in treating moles. Fairly minor procedures (involving the surgical excision of the entire lesion) can easily remove moles. Moles and skin tags can easily be removed with the laser treatment also ${ }^{8}$.

In Ayurveda classics, Acharya Sushruta has described the treatment of Masaka. It should be excised and then slowly burnt with caustic alkali (Kshara karma) or Cautery (Agnikarma) ${ }^{9}$. Caustic alkali is used for those who are fit for cauterization otherwise.

Kshara is an alkaline Ayurvedic preparation. Kshara, being a caustic chemical and alkaline in nature, is useful as the substitute of surgical instruments. It is milder procedure than surgery. It is the superior most among the sharp and subsidiary instrument because it can perform activities like excision, incision and scraping ${ }^{10}$.

Agnikarma means application of Agni (heat) directly or indirectly with the help of different materials over affected or indicated area. Dalhana, commentator of Sushruta Samhita classified Agnikarma as karma or action carried out by Agni. Acharya Sushruta has described Agnikarma in various disorder of skin ${ }^{11}$. Acharya Sushruta has explained that the disease treated with Agnikarma will not reoccur ${ }^{12}$. 


\section{MATERIALS AND METHODS}

A male patient aged about 42 years visited Shalya Tantra OPD, National Institute of Ayurveda, Jaipur, with complaints of a blackish brown coloured growth present on his face Right side (infraorbital region). With time the discoloured growth gradually increased its size in last 15 years. Patient was not having any chronic illness like HTN, DM and Thyroid dysfunction. Patient was thoroughly examined and vitals were taken. Local examination was performed which revealed elevated mole present on Right side of face at infraorbital region. Patient was diagnosed case of elevated mole. General condition was fair, B.P110/70 mmHg, P.R- 82/Min and Temperature was afebrile.

\section{Investigations}

Routine investigations viz. $\mathrm{Hb} \%$, TLC, DLC, ESR, RBS, HIV, HBsAg, RFT, ECG, Chest X -Ray PA view, UrineRoutine/Microscopic were done. All investigations were within normal limits.

\section{Treatment Plan}

The treatment regimen was planned as Excision of elevated mole by Agnikarma followed by Ksharkarma ${ }^{13}$.
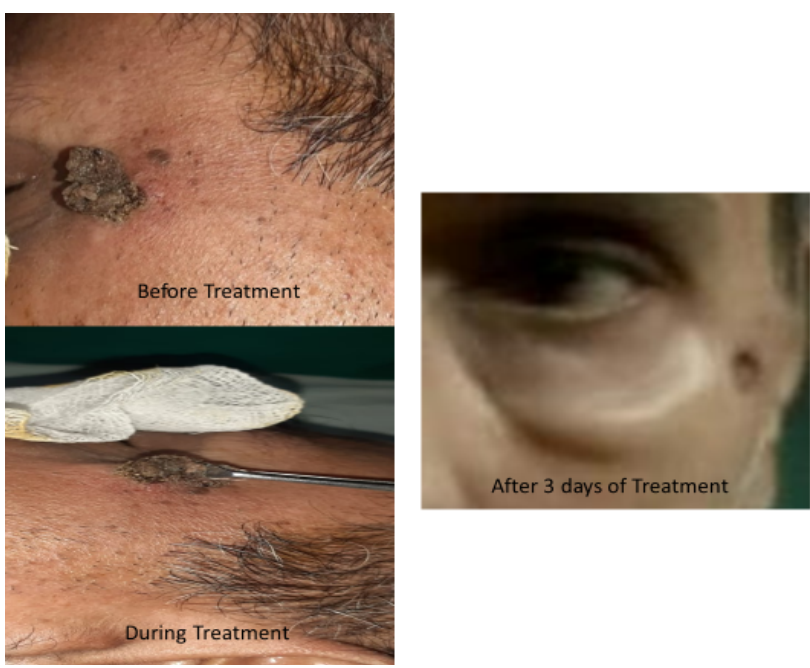

\section{DISCUSSION}

Excision is the main treatment of the elevated mole. But there's a high chance of recurrence. Excision of mole with Agnikarma followed by Kshara karma is the best treatment. There is less risk of recurrence and limited scar development. Agnikarma can be recommended as an emerging alternative to surgery with minimal post procedure complications. Kshara karma is a conducive, day care procedure and is very cost effective, which can be performed under local anaesthesia with minimal and trivial post procedure. Complications are negligible.

\section{CONCLUSION}

The probable mode of action of Pratisarneeya Kshara is, as it creates a chemical burn on the area where it is applied, which

\section{Procedure}

Patient was educated about the whole procedure and his consent was taken. Tetanus toxoid prophylaxis was given and written informed consent was taken before the procedure. The procedure was performed under local anaesthesia. A Shalaka was taken and kept it red hot on high flame and excision of mole was done by this Shalaka. Application of Apamarga pratisarneeya tikshna kshara was done at the same site till Pakwa Jamboophala Varna was achieved. Then it was washed by distilled water and later neutralized by the application of lemon juice. Complete haemostasis was achieved and antiseptic dressing was done with Jatyadi tail.

Patient was advised Pathya-Apathya, Ahara-Vihara and regular follow up. Oral medications, Triphala guggulu $500 \mathrm{mg}$ tablets twice daily and daily cleaning and dressing with Jatyadi tail was given for 15 days.

\section{Follow Up}

Regular follow up was done weekly for 2 months. On follow up patient was satisfied with the treatment. There was no pain and scar. There were no complaints of recurrence.

\section{RESULT}

Significant improvement was observed in treatment of elevated mole. No burning pain and scar was seen. No any side effect or complication was observed during treatment and follow up periods.

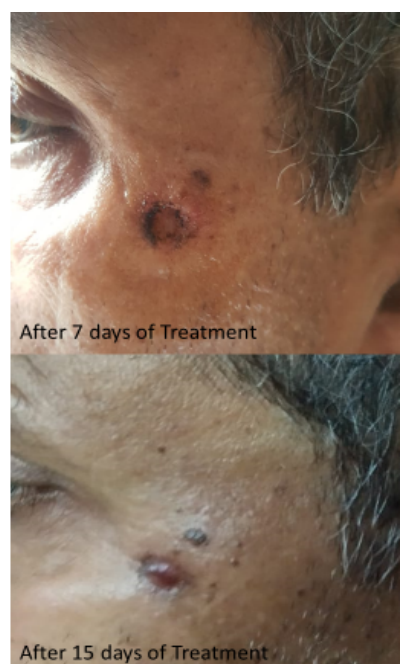

causes cicatrisation (in wound healing process) and burns remaining tissues so recurrence is less. Study on large sample size is needed to establish the effect of Agnikarma and Kshara karma in elevated mole.

\section{REFERENCES}

1. Moles: Causes, Symptoms, Types \& Removal [Internet]. Medicine Net. 2020 [cited 8 June2020]. Available from: https://www.medicinenet.com/moles/article.htm\# what_are_moles

2. Health E, Disease H, Disease L, Management P, Conditions $\mathrm{S}$ et al. Moles, Freckles, Skin Tags, and More [Internet]. WebMD. 2020 [cited 8 June 2020]. Available from: https://www.webmd.com/skin-problems-and-treatments/ guide/moles-freckles-skin-tags\#2 
3. Moles: Causes, Symptoms, Types and Removal [Internet]. Medicine Net. 2020 [cited 8 June2020]. Available from: https://www.medicinenet.com/moles/article.htm\# what_are_moles

4. [Internet]. 2020 [cited 8 June 2020]. Available from: https://www.webmd.com/skin-problems-andtreatments/guide/moles-freckles-skin-tags\#2

5. Sushruta, Sushruta Samhita with Nibandha Sangraha commentary of Dalhana acharya edited by Vaidya Yadavji Trikamji Acharya, $1^{\text {st }}$ Ed. Varanasi: Chaukhambha Surabharti Prakashan; 2017. p. 323, 724

6. Sushruta, Sushruta Samhita with Nibandha Sangraha commentary of Dalhana acharya edited by Vaidya Yadavji Trikamji Acharya, $1^{\text {st }}$ Ed. Varanasi: Chaukhambha Surabharti Prakashan; 2017. p. 323, 724.

7. Health E, Disease H, Disease L, Management P, Conditions S et al. Moles, Freckles, Skin Tags, and More [Internet]. Web MD. 2020 [cited 8 June 2020]. Available from: https://www.webmd.com/skin-problems-andtreatments/guide/moles-freckles-skin-tags\#2

8. Skin moles treatment: what are your options for mole removal [Internet]. Skin Vision. 2020 [cited 8 June 2020]. Available from: https://www.skinvision.com/articles/skin-molestreatment-what-are-your-options-for-mole-removal/

9. Sushruta, Sushruta Samhita with Nibandha Sangraha commentary of Dalhana acharya edited by Vaidya Yadavji
Trikamji Acharya, $1^{\text {st }}$ Ed. Varanasi: Chaukhambha Surabharti Prakashan; 2017. p. 480, 724.

10. Sushruta, Sushruta Samhita with Nibandha Sangraha commentary of Dalhana acharya edited by Vaidya Yadavji Trikamji Acharya, $1^{\text {st }}$ Ed. Varanasi: Chaukhambha Surabharti Prakashan; 2017. p. 45, 724.

11. Sushruta, Sushruta Samhita with Nibandha Sangraha commentary of Dalhana acharya edited by Vaidya Yadavji Trikamji Acharya, $1^{\text {st }}$ Ed. Varanasi: Chaukhambha Surabharti Prakashan; 2017. p. 52, 724.

12. Sushruta, Sushruta Samhita with Nibandha Sangraha commentary of Dalhana acharya edited by Vaidya Yadavji Trikamji Acharya, $1^{\text {st }}$ Ed. Varanasi: Chaukhambha Surabharti Prakashan; 2017. p. 51, 724

13. Sushruta, Sushruta Samhita with Nibandha Sangraha commentary of Dalhana acharya edited by Vaidya Yadavji Trikamji Acharya, $1^{\text {st }}$ Ed. Varanasi: Chaukhambha Surabharti Prakashan; 2017. p. 480, 724.

\section{Cite this article as:}

Himadri Mudgal and P. Hemantha Kumar. Pertinence of Kshara karma and Agni karma in the management of Masaka with special reference to elevated mole: A Case Study. Int. J. Res. Ayurveda Pharm. 2020;11(5):22-24 http://dx.doi.org/10.7897/2277$\underline{4343.1105134}$

Disclaimer: IJRAP is solely owned by Moksha Publishing House - A non-profit publishing house, dedicated to publishing quality research, while every effort has been taken to verify the accuracy of the content published in our Journal. IJRAP cannot accept any responsibility or liability for the site content and articles published. The views expressed in articles by our contributing authors are not necessarily those of IJRAP editor or editorial board members. 